\title{
EVALUATION OF BUILDINGS' REDEVELOPMENT ALTERNATIVES WITH AN EMPHASIS ON THE MULTIPARTITE SUSTAINABILITY
}

\author{
Edmundas Kazimieras ZAVADSKAS ${ }^{1}$ and Jurgita ANTUCHEVIČIENE் ${ }^{2}$ \\ Department of Building Technology and Management, Vilnius Gediminas Technical University, \\ Sauletekio al. 11, LT-10223 Vilnius-40, Lithuania \\ 1 Tel.: +370 5274 5002; fax.+370 5270 0114; e-mail: edmundas.zavadskas@adm.vtu.lt \\ ${ }^{2}$ Tel.: +370 527447 01, +370 527452 32; e-mail: jurgita.antucheviciene@st.vtu.lt
}

Received 15 December 2003; accepted 21 April 2004

\begin{abstract}
The authors analyse the problem of derelict buildings' redevelopment by means of multi criterion decision-making techniques. The aim of the research is to rank derelict buildings' redevelopment alternatives from the multiple sustainability approach. Moreover, handling of MCDM techniques is discussed. The MCDM techniques used are: technique for order preference by similarity to ideal solution (TOPSIS) and compromise ranking method (VIKOR). A Lithuanian case study is presented to illustrate similarities and differences of ranking results using these methods in particular situation. The comparisons of the results after multiple criteria analysis implementation are made in the paper and scientific recommendations for a sustainable redevelopment of derelict buildings in Lithuanian rural areas are suggested on a basis of calculations.
\end{abstract}

KEYWORDS: Derelict buildings; Buildings' redevelopment; MCDM; TOPSIS; VIKOR

\section{INTRODUCTION}

One of the most perpetual challenges in science and engineering is how to make the optimal decision in a given situation. Theories such as linear programming, dynamic programming, hypothesis testing, inventory control, optimisation and multi-criteria decision-making (MCDM) are used in searching for an optimal solution.

Contemporary decision problems in the field of construction and engineering are characterized by a diversity of structures and processes, hardly commensurable variables, conflicting development objectives and constraints. Different stakeholders with different interests and values interacting with each other make the decision-making process much more complicated. If we are to look for a solution to the problem, we must face a multi-dimensional approach. Therefore, multi-criteria techniques seem to be an appropriate tool in ranking or selecting one or more alternatives from a set of available alternatives with respect to multiple, usually conflicting criteria.

A large number of methods have been developed for solving multi-criteria problems (Hwang and Yoon, 1981; Triantaphyllou, 2000). MCDM frameworks vary from simple approaches requiring very little information to methods based on mathematical programming techniques, requiring extensive information on each attribute and the preferences of the decision makers. Complex classification of mentioned methods is presented in several publications (Roy, 1996; Zavadskas, Kaklauskas and Banaitienè, 2001; Greening and Bernow, 2004; Guitouni and Martel, 1998). But still it is a problem of choosing an appropriate method in a given situation. None of them can be considered as the best and appropriate to all deci- 
sion-making situations. Handling of MCDM depends on a particular case, on the aim of research and, especially, on quality and reliability of the data.

In our case study, revitalization of derelict and mismanaged buildings in Lithuanian rural areas is analyzed. A multiple sustainable development approach is used for finding rational development trends of abandoned rural buildings. The economic benefit of revitalization of property is combined with the environmental potential as well as social interest for amount of reasons (Antuchevičienè, 2002, 2003a). In this paper, the problem of derelict buildings' management is analyzed by means of multi criterion decision-making techniques.

The aim of the research is to adapt appropriate MCDM techniques for ranking of derelict buildings' redevelopment alternatives from the multiple sustainability approach, compare the results and discuss the handling of multi-criteria decision-making techniques in particular case. The authors made observations, how much the significance of alternatives and series of priorities changed subject to changes in decision-making technique in ranking of buildings' revitalisation alternatives.

In our case study, the MCDM techniques used are: technique for order preference by similarity to ideal solution (TOPSIS) with two different normalization methods (vector and linear) (Hwang and Yoon, 1981) and compromise ranking method (VIKOR) (Opricovic and Tzeng, 2004).

\section{DESCRIPTION OF MCDM METHODS, USED IN THE ANALYSIS}

Two multiple criteria decision-making methods - VIKOR and TOPSIS, represent closeness to the reference points. But these two methods introduce different forms of aggregating function for ranking and they use different kinds of normalization to eliminate the units of criterion.
Both methods evaluate the decision matrix, which refers to $\mathrm{n}$ alternatives that are evaluated in terms of $m$ criteria. The member $f_{i j}$ denotes the performance measure of the $j$-th alternative in terms of the $i$-th criterion.

TOPSIS (the Technique for Order Preference by Similarity to Ideal Solution) was developed by Hwang and Yoon (1981). The basic concept of the TOPSIS method is that the selected alternative should have the shortest distance from the ideal solution and the farthest distance from the negative-ideal solution, in a geometrical sense.

The first step of the procedure of every multiple criteria decision-making method is to calculate the normalized decision matrix. Considering the opinion, that there are normalization procedures with effects on the final MCDM result (Opricovic and Tzeng, 2004), two normalization methods were used in TOPSIS technique. The classical TOPSIS uses vector normalization (Hwang and Yoon, 1981; Triantaphyllou, 2000; Zavadskas, Kaklauskas and Banaitienè, 2001):

$$
r_{i j}=\frac{f_{i j}}{\sqrt{\sum_{j=1}^{n} f_{i j}^{2}}},
$$

where $r_{i j}$ is normalized value, $i=1, \ldots, m$; $j=1, \ldots, n$.

Lai and Hwang (1994) introduced linear normalization into the TOPSIS:

$$
\begin{aligned}
& r_{i j}=\frac{f_{i j}}{\left(f_{i}^{*}-f_{i}^{-}\right)}, i \in I^{\prime} \text { (benefits), } \\
& r_{i j}=\frac{f_{i j}}{\left(f_{i}^{-}-f_{i}^{*}\right)}, i \in I^{\prime \prime} \text { (costs), }
\end{aligned}
$$

where $f_{i}^{*}=\max f_{i j}, f_{i}^{-}=\min f_{i j}$.

Technique for ${ }^{j}$ Order Preference by Similarity to Ideal Solution is well known and applied for engineering problems. Zavadskas have been applying TOPSIS method for construction solutions since 1986 (Zavadskas, 1986; 
Zavadskas, Fiedler and Peldschus, 1986). Seeing that TOPSIS method is widely applied (Triantaphyllou, 2000; Zavadskas, Kaklauskas and Banaitiene, 2001; Opricovic and Tzeng, 2004; Tsaur, Chang and Yen, 2002; Vilutiené and Zavadskas, 2003; Cheng, Chang and Huang, 2003; Tong et. al., 2004; Montanari, The compromise ranking method (called VIKOR) was newly developed and presented by Opricovic (Opricovic, 1998; Opricovic and Tzeng, 2004). It is used for engineering goals one of the first times by the authors of this paper.

The VIKOR method is also based on an aggregating function, representing closeness to the ideal point. The distinction of this method is, that it determines a compromise solution and considers the relative importance of distances to ideal and negative solutions.

The first step of the compromise ranking algorithm is to determine the best $f_{i}^{*}$ and the worst $f_{i}^{-}$values of all criterion functions, $i=1, \ldots, m$. If the $i$-th function represents a benefit then:

$$
f_{i}^{*}=\max _{j} f_{i j}, f_{i}^{-}=\min _{j} f_{i j} .
$$

The following step after the determination of the best $f_{i}^{*}$ and the worst $f_{i}^{-}$values of criterion functions is computation of the values $S_{j}, R_{j}$ and $Q_{j}$ (Opricovic and Tzeng, 2004):

$$
\begin{gathered}
S_{j}=\sum_{i=1}^{m} w_{i}\left(f_{i}^{*}-f_{i j}\right) /\left(f_{i}^{*}-f_{i}^{-}\right), \\
R_{j}=\max _{i} S_{j}, \\
Q_{j}=v\left(S_{j}-S^{*}\right) /\left(S^{-}-S^{*}\right)+(1-v)\left(R_{j}-R^{*}\right) /\left(R^{-}-R^{*}\right),
\end{gathered}
$$

where $S^{*}=\min _{j} S_{j}, S^{-}=\max _{j} S_{j}, R^{*}=\min _{j} R_{j}$, $R^{-}=\max _{j} R_{j}, w_{i}$ is the weight (or significance) of the $i$-th criterion, $v$ is introduced as weight of the strategy of "the maximum group utility". Here $v=0,5$, and it means, that compromise solution is stable within the decision making process by consensus. (When $v>0,5$, 'voting by majority rule' is needed; when $v<0,5$, solution is stable within the decision making process 'with veto').

After this, alternatives should be sorted by values $S, R$ and $Q$ in increasing order. The best alternative $A^{\prime}$ is the one with the minimum value $Q$ if two complementary conditions are satisfied (Opricovic and Tzeng, 2004):

C1. 'Acceptable advantage':

$$
Q\left(A^{\prime \prime}\right)-Q\left(A^{\prime}\right) \geq D Q \text {, }
$$

where $A^{\prime \prime}$ is the alternative with second position in the ranking list by $Q ; D Q=1 /(J-1)$; $J$ is the number of alternatives.

C2. 'Acceptable stability in decision making': $A^{\prime}$ must also be the best ranked by $S$ or/and $R$.

If one of the conditions is not satisfied, then a set of compromise solutions with the advantage rate is proposed instead of the only best alternative, which consists of alternatives $A^{\prime}$ and $A^{\prime \prime}$ if only condition C2 is not satisfied, or alternatives $A^{\prime}, A^{\prime \prime}, \ldots, A^{(N)}$ if condition $\mathrm{C} 1$ is not satisfied; and $A^{(N)}$ is determined by the relation $Q\left(A^{(N)}\right)-Q\left(A^{\prime}\right)<D Q$ for maximum $N$ (the positions of these alternatives are 'in closeness').

\section{RANKING OF BUILDINGS' REDEVELOPMENT ALTERNATIVES}

A Lithuanian case study is presented to illustrate similarities and differences of ranking results using the both methods in particular situation. Revitalization of derelict and mismanaged buildings in Lithuanian rural areas is analysed in the paper. These objects were built in the time of Soviet occupation, 
mostly for farming and partly for rural infrastructure. Due to political, economical changes and reorganization of the agricultural sector, they are derelict and mismanaged at present.

Some results of previous authors' research in the field of deteriorated property redevelopment have been published already. They included observations of rural buildings territorial distribution peculiarities and establishment of factors, determining distribution and revitalisation perspectives of abandoned buildings, using methods of mathematical statistics. It was estimated that the peculiarities of derelict and mismanaged buildings territorial distribution are statistically different in various zones of development activity as presented in the conception of Lithuania's spatial development (Antuchevičiene, 2002, 2003a, 2003b).

Sustainable development approach was used for identifying rational development trends of abandoned rural buildings. Revitalisation of buildings should be a contribution towards sustainable construction, incorporating protection of natural and social environmental, improvement of life quality and implementation of economic goals. Therefore, existing sustainability indicator systems and theoretical recommendations were analysed and a system of criteria was developed according to the common principles of sustainable development and to explored local peculiarities (Antuchevičienè, 2003a).

In this paper, the above-mentioned indicator system is fitted for multiple criteria decision-making and calculations are performed, determining redevelopment priorities of buildings. In our case study, there are three alternatives and fifteen criteria. The alternatives include reconstruction of rural buildings and adapting them for production (or commercial) activity (alternative $A_{1}$ ), using them for farming purposes (alternative $A_{2}$ ) or demolition and recycling of demolition waste (alternative $A_{3}$ ). Criteria consist of mainly three conflicting types of interest: economic, ecological and social. The criteria are based on sustainability indicators and represent three typological groups in sustainable decision-making, pro- posed by the authors in preceding research: current state abandoned buildings and their environment, development (or revitalization) possibilities and impact after the implementation of particular redevelopment alternative (Antuchevičienè, 2003a). The following fifteen criteria (or sustainability indicators) in evaluating building revitalization alternatives have been taken into consideration, including the average soil fertility grade in the area $f_{1}$ (points), quality of life parameters of the local population $f_{2}$ (points), population activity in$\operatorname{dex} f_{3}(\%)$, GDP in proportion to the average GDP of the country $f_{4}(\%)$, material investments in the area $f_{5}$ (Lt / resident), foreign investments in the area $f_{6}\left(\mathrm{Lt} \times 10^{3} /\right.$ resident), building redevelopment costs $f_{7}\left(\right.$ Lt $\left.\times 10^{6}\right)$, increase of income of the local population $f_{8}$ (Lt $\times 10^{6} /$ year), increase of sales in the area $f_{9}$ $(\%)$, increase of employment $f_{10}(\%)$, state income from business and property taxes $f_{11}$ (Lt $\times 10^{6} /$ year), business outlook $f_{12}$, difficulties of purpose-built changes $f_{13}$, degree of contamination $f_{14}$, attractiveness of the countryside (i.e. image, landscape quality and the like) $f_{15} . f_{2}, f_{7}, f_{13}$ and $f_{14}$ are associated with cost criteria (their less value is better), while the remaining attributes are associated with benefit criteria (their greater value is better). The choice of indicators is limited by the available data, but their use demonstrates the procedure of the proposed model.

The values of the criteria are estimated according to official statistical data and on the basis of the previous research made by the authors. The ratings of qualitative attributes $f_{12}, f_{13}, f_{14}$ and $f_{15}$ are expressed with the help of linguistic variables, used in fuzzy decisionmaking ( $\mathrm{Li}$ and Yang, 2004). For example, the performance ratings of alternatives on qualitative attributes could be expressed using linguistic variable such as very poor, poor, fair, good, very good, etc. Such linguistic values can be represented using numbers 0,$1 ; 0,3 ; 0,5 ; 0,7$; 0,9 , respectively. The initial data of the performance measure of the $j$-th alternative in terms of the $i$-th criterion is presented in Table1. 
Table 1. Initial data for derelict buildings' revitalization multi-criteria analysis implementation

\begin{tabular}{|c|c|c|c|c|c|c|c|c|c|c|c|c|}
\hline \multirow{3}{*}{$\begin{array}{l}\text { Crite- } \\
\text { ria, } f_{i}\end{array}$} & \multicolumn{12}{|c|}{ Value of criteria, $f_{i j}$} \\
\hline & \multicolumn{4}{|c|}{ Area of active development } & \multicolumn{4}{|c|}{ Area of regressing development } & \multicolumn{4}{|c|}{ 'Buffer' area } \\
\hline & $w_{i}$ & $A_{1}$ & $A_{2}$ & $A_{3}$ & $w_{i}$ & $A_{1}$ & $A_{2}$ & $A_{3}$ & $w_{i}$ & $A_{1}$ & $A_{2}$ & $A_{3}$ \\
\hline$\overline{f_{1}}$ & 0.9 & 40.3 & 40.3 & 40.3 & 1.11 & 36.7 & 36.7 & 36.7 & 0.83 & 39.5 & 39.5 & 39.5 \\
\hline$f_{2}$ & 1.09 & 31.4 & 31.4 & 31.4 & 0.92 & 29.2 & 29.2 & 29.2 & 0.85 & 30.0 & 30.0 & 30.0 \\
\hline$f_{3}$ & 1.12 & 53.2 & 53.2 & 53.2 & 0.94 & 56.4 & 56.4 & 56.4 & 1.25 & 54.8 & 54.8 & 54.8 \\
\hline$f_{4}$ & 0.94 & 103.2 & 103.2 & 103.2 & 0.92 & 103.8 & 103.8 & 103.8 & 0.83 & 78.6 & 78.6 & 78.6 \\
\hline$f_{5}$ & 1.01 & 1805.7 & 1805.7 & 1805.7 & 1.11 & 1559.6 & 1559.6 & 1559.6 & 1.12 & 806.2 & 806.2 & 806.2 \\
\hline$f_{6}$ & 0.94 & 1754.0 & 1754.0 & 1754.0 & 1.01 & 1463.9 & 1463.9 & 1463.9 & 1.12 & 284.1 & 284.1 & 284.1 \\
\hline$f_{7}$ & 1 & 358.4 & 77.6 & 14.4 & 1 & 312.3 & 58.9 & 12.6 & 1 & 378.3 & 71.4 & 15.2 \\
\hline$f_{8}$ & 1 & 114.0 & 27.4 & 0.6 & 1 & 99.4 & 23.8 & 0.6 & 1 & 120.4 & 28.9 & 0.7 \\
\hline$f_{9}$ & 1 & 18.5 & 2.5 & 0.0 & 1 & 100.2 & 13.7 & 0.0 & 1 & 113.1 & 15.5 & 0.0 \\
\hline$f_{10}$ & 1 & 5.0 & 1.5 & 0.0 & 1 & 3.8 & 1.2 & 0.0 & 1 & 12.5 & 1.7 & 0.0 \\
\hline$f_{11}$ & 1 & 26.9 & 5.9 & 0.3 & 1 & 24.5 & 5.1 & 0.2 & 1 & 29.6 & 6.2 & 0.3 \\
\hline$f_{12}$ & 1 & 0.9 & 0.3 & 0.7 & 1 & 0.3 & 0.5 & 0.1 & 1 & 0.5 & 0.3 & 0.3 \\
\hline$f_{13}$ & 1 & 0.9 & 0.1 & 0.7 & 1 & 0.5 & 0.1 & 0.1 & 1 & 0.9 & 0.1 & 0.5 \\
\hline$f_{14}$ & 1 & 0.7 & 0.5 & 0.1 & 1 & 0.5 & 0.1 & 0.1 & 1 & 0.3 & 0.1 & 0.1 \\
\hline$f_{15}$ & 1 & 0.7 & 0.5 & 0.3 & 1 & 0.7 & 0.7 & 0.5 & 1 & 0.9 & 0.5 & 0.7 \\
\hline
\end{tabular}

Weights (or significances) of criteria are determined according to previous research. While calculating by the ideal point methods, the sum of significances shall not be limited by any value. So weights of criteria, representing current state of buildings and their environment, were estimated in proportion to measured correlation relationship (Antuchevičienè, 2002, 2003b). Criteria, representing revitalization possibilities and impact after the implementation of particular redevelopment alternative, were considered to be of equal importance, and significances of these criteria were equated to 1 .

Abandoned buildings' management is analysed separately in three zones of development activity (area of active development, area of regressing development and 'buffer' area) as presented in the conception of Lithuania's spatial development (Juškevičius, 1999). For description of areas, see (Antuchevičienè, 2002, 2003a, 2003b) with reference to (Juškevičius, 1999).

Calculations are made according to two main strategic goals for the regional policy as presented in the Comprehensive plan of the territory of the Republic of Lithuania, namely maintenance of existing potential in a region and equilibration of salutatory evolution of regions.

\section{COMPARISON OF RANKING RESULTS}

Three MCDM techniques were used for ranking of alternatives in the case study: technique for order preference by similarity to ideal solution (TOPSIS) with two different normalization methods (vector and linear) and compromise ranking method (VIKOR) (for description of methods see chapter 2). Partial results of ranking rural buildings' redevelopment alternatives, using TOPSIS method, were announced at international conference on sustainability indicators and intelligent decisions (Antuchevičienė and Zavadskas, 2003c, 2003d). The comparison of the results after multiple criteria analysis implementation showed that there were some ranking differences between the methods. Significance of al- 
ternatives and series of priorities changed subject to changes in decision-making technique in ranking of buildings' revitalisation alternatives. We can conclude, that the normalization method has a rather strong influence on ranking results, because ranking lists, obtained using technique for order preference by similarity to ideal solution with vector and linear normalization, differ. VIKOR has more similarities with TOPSIS that uses linear normalization. According to Opricovic and Tzeng (2004), the normalized values by vector normalization may depend on the evaluation unit. Moreover, these two methods introduce different aggregating functions for ranking. The compromise ranking method introduces the relative importance of the criteria and a balance between total and individual satisfaction (weight $v$ in Eq. (6)). While the distances from the ideal point and from the negative-ideal point in technique for order preference by similarity to ideal solution are simply summed, without considering their relative importance.

The results of applying a multi-criteria analysis are presented in Table 2.

In spite of some ranking differences, scientific recommendations for a sustainable revitalization of derelict buildings could be prepared on a basis of calculations. One ought to make renovations and use buildings not for farming in the areas of active development. In regressing or other localities these buildings can be effectively used for farming purposes and there are less possibilities of changing their functions successfully. Damaged and not useful for farming objects should be dismantled, recycled and reused.

\section{CONCLUSIONS}

1. Multiple-criteria analysis of abandoned buildings' redevelopment alternatives in

Table 2. Results obtained by TOPSIS and VIKOR

\begin{tabular}{|c|c|c|c|c|c|c|c|}
\hline \multirow{2}{*}{$\begin{array}{l}\text { MCDM } \\
\text { method }\end{array}$} & \multirow[t]{2}{*}{ Area } & \multirow[t]{2}{*}{ Strategy } & \multirow{2}{*}{$\begin{array}{l}\text { The } \\
\text { relative } \\
\text { factor }\end{array}$} & \multicolumn{3}{|c|}{ Redevelopment alternatives } & \multirow[t]{2}{*}{ Ranking } \\
\hline & & & & $A_{1}$ & $A_{2}$ & $A_{3}$ & \\
\hline \multirow{6}{*}{$\begin{array}{l}\text { TOPSIS } \\
\text { vector } \\
\text { normalization }\end{array}$} & \multirow{2}{*}{$\begin{array}{l}\text { Active } \\
\text { development }\end{array}$} & $\mathrm{MEP}^{*}$ & $C$ & 0.61 & 0.41 & 0.36 & $A_{1} \succ A_{2} \succ A_{3}$ \\
\hline & & $\mathrm{ESE}^{* *}$ & $C$ & 0.53 & 0.49 & 0.36 & $A_{1} \succ A_{2} \succ A_{3}$ \\
\hline & \multirow{2}{*}{$\begin{array}{l}\text { Regressing } \\
\text { development }\end{array}$} & MEP* & $C$ & 0.50 & 0.56 & 0.46 & $A_{2} \succ A_{1} \succ A_{3}$ \\
\hline & & $\mathrm{ESE}^{* *}$ & C & 0.61 & 0.45 & 0.46 & $A_{1} \succ A_{3} \approx A_{2}$ \\
\hline & \multirow[t]{2}{*}{ 'Buffer' } & MEP* & $C$ & 0.59 & 0.43 & 0.38 & $A_{1} \succ A_{2} \succ A_{3}$ \\
\hline & & ESE** $^{* *}$ & $C$ & 0.61 & 0.47 & 0.36 & $A_{1} \succ A_{2} \succ A_{3}$ \\
\hline \multirow{6}{*}{$\begin{array}{l}\text { TOPSIS } \\
\text { linear } \\
\text { normalization }\end{array}$} & \multirow{2}{*}{$\begin{array}{l}\text { Active } \\
\text { development }\end{array}$} & $\mathrm{MEP}^{*}$ & $C$ & 0.62 & 0.42 & 0.37 & $A_{1} \succ A_{2} \succ A_{3}$ \\
\hline & & $\mathrm{ESE}^{* *}$ & $C$ & 0.49 & 0.54 & 0.37 & $A_{2} \succ A_{1} \succ A_{3}$ \\
\hline & \multirow{2}{*}{$\begin{array}{l}\text { Regressing } \\
\text { development }\end{array}$} & MEP* & $C$ & 0.46 & 0.64 & 0.48 & $A_{2} \succ A_{3} \approx A_{1}$ \\
\hline & & $\mathrm{ESE}^{* *}$ & $C$ & 0.62 & 0.46 & 0.48 & $A_{1} \succ A_{3} \approx A_{2}$ \\
\hline & \multirow[t]{2}{*}{ 'Buffer' } & $\mathrm{MEP}^{*}$ & $C$ & 0.47 & 0.37 & 0.53 & $A_{3} \succ A_{1} \succ A_{2}$ \\
\hline & & $\mathrm{ESE}^{* *}$ & $C$ & 0.64 & 0.55 & 0.35 & $A_{1} \succ A_{2} \succ A_{3}$ \\
\hline \multirow[t]{6}{*}{ VIKOR } & \multirow{2}{*}{$\begin{array}{l}\text { Active } \\
\text { development }\end{array}$} & MEP* & $Q$ & 0.38 & 0.36 & 1.00 & $A_{2} \approx A_{1} \succ A_{3}$ \\
\hline & & $\mathrm{ESE}^{* *}$ & $Q$ & 0.65 & 0.00 & 1.00 & $A_{2} \succ A_{1} \succ A_{3}$ \\
\hline & \multirow{2}{*}{$\begin{array}{l}\text { Regressing } \\
\text { development }\end{array}$} & $\mathrm{MEP}^{*}$ & $Q$ & 1.00 & 0.00 & 0.64 & $A_{2} \succ A_{3} \succ A_{1}$ \\
\hline & & $\mathrm{ESE}^{* *}$ & $Q$ & 0.00 & 1.00 & 0.45 & $A_{1} \succ A_{3} \nearrow_{2}$ \\
\hline & \multirow[t]{2}{*}{ 'Buffer' } & MEP* & $Q$ & 0.67 & 1.00 & 0.00 & $A_{3} \succ A_{1} \succ A_{2}$ \\
\hline & & ESE** & $Q$ & 0.00 & 0.17 & 1.00 & $A_{1} \succ A_{2} \succ A_{3}$ \\
\hline
\end{tabular}

\footnotetext{
* Maintenance of existing potential in a region.

** Equilibration of saltatory evolution of regions.
} 
Lithuanian rural areas was performed and different priorities of sustainable redevelopment alternatives were determined in areas of active, middle and regressing development. It has been found that the same solution is hardly applicable to any object and over the whole territory of a country.

2. Two MCDM methods, representing closeness to the reference points, have been used. Multiple-criteria analysis indicated that there were some ranking differences between the used methods. However, the results were consistent enough to prepare some scientific recommendations for a sustainable revitalization of derelict buildings.

3. The utility degree of the best redevelopment alternative compared to the worst one ranged from $18 \%$ to $45 \%$ (Topsis method) or from $64 \%$ to $100 \%$ (VIKOR method), depending on the particular terrain and the strategic goals of regional development.

4. No unambiguous answer was offered about the best multi-criteria technique. Handling of MCDM depends on a particular case. In a case of ranking of sustainable buildings' redevelopment, the type of uncertainty related to sustainable development must be considered. Consequently, we should apply a less sensitive method, obviating false series of priorities due to quality of the data in this case.

\section{REFERENCES}

Antuchevičienė, J. (2002) Territorial distribution peculiarities of derelict rural buildings in Lithuania according to the conception of the country's economic, social and ecological sustainable development. Aplinkos inžinerija, 10(2), p. 93-101 (in Lithuanian).

Antuchevičienè, J. (2003a) Principles of revitalization of derelict rural buildings. Journal of Civil Engineering and Management, 9(4), p. 225-233.

Antuchevičienè, J. (2003b) Regional differences of mismanaged used rural buildings. Tiltai, 24(3), p. 53-61 (in Lithuanian).

Antuchevičienè, J., Zavadskas, E. K. (2003c) The indicator model for sustainable revitalization of rural property. Abstracts of papers of the International Conference on Sustainability Indicators and Intelligent Decisions, October 911, 2003, Vilnius, Lithuania, p. 23-24.

Antuchevičienè, J., Zavadskas, E. K. (2003d) The indicator model for sustainable revitalization of rural property. Environmental Research, Engineering and Management, 4(26), p. 38-44.

Cheng, S., Chan, C. W., Huang, G. H. (2003) An integrated multi-criteria decision analysis and inexact mixed integer linear programming approach for solid waste management. Engineering Applications of Artificial Intelligence, 16(56), p. 543-554.

Greening, L. A, Bernow, S. (2004) Design of coordinated energy and environmental policies: use of multi-criteria decision-making. Energy Policy, 32, p. 721-735.

Guitouni, A., Martel, J. -M. (1998) Tentative guidelines to help choosing an appropriate MCDA method. European Journal of Operational Research, 109, p. 501-521.

Hwang, C. L., Yoon, K. (1981) Multiple Attribute Decision Making Methods and Applications. Berlin, Heidelberg, New York: Springer Verlag.

Juškevičius, P. (1999) The concept of the country's spatial development. Urbanistika ir architektūra, 13(2), p. 49-55 (in Lithuanian).

Lai, Y. J., Hwang, C. L. (1994) Fuzzy Multiple Objective Decision Making: Methods and Applications. Springer - Verlag, Berlin.

Li, D.-F., Yang, J. -B. (2004) Fuzzy linear programming technique for multiattribute group decision making in fuzzy environments. Information Sciences, 158, p. 263-275.

Montanari, R. (2004) Environmental efficiency analysis for enel thermo-power plants. Journal of Cleaner Production, 12(4), p. 403-414.

Opricovic, S. (1998) Multicriteria Optimization of Civil Engineering Systems. Faculty of Civil Engineering, Belgrade.

Opricovic, S., Tzeng, G. -H. (2004) Compromise solution by MCDM methods: A comparative analysis of VIKOR and TOPSIS. European Journal of Operational Research, 156(2), p. 445-455.

Roy, B. (1996) Multictriteria Methodology for Decision Aiding. Dortrecht: Kluwer Academic Publishers. 
Tong, L. I., Wang, Ch. H., Chen, Ch. Ch., Chen, Ch. T. (2004) Dynamic multiple responses by ideal solution analysis. European Journal of Operational Research, 56(2), p. 433-444.

Triantaphyllou, E. (2000) Multi-criteria Decision Making Methods: a Comparative Study. Kluwer Academic Publishers.

Tsaur, S. -H., Chang, T. -Y., Yen, Ch. -H. (2002) The evaluation of airline service quality by fuzzy MCDM. Tourism Management, 23, p. 107-115.

Vilutiene, T., Zavadskas, E. K. (2003) The application of multi-criteria analysis to decision support for the facility management of a residential district. Journal of Civil Engineering and Management, 9(4), p. 241-252.
Zavadskas, E. K. (1986) The method of ranking of construction-technological alternatives on the basis of the distance from the ideal solution. New Construction Technology for Buildings and Structures, Leningrad, p. 42-44.

Zavadskas, E. K., Fiedler, K., Peldschus, F. (1986) Methoden der bautechnologischen Entscheidung. Technische Hochschule Leipzig (in German).

Zavadskas, E. K., Kaklauskas, A., Banaitienè, N. (2001) Multiple Criteria Analysis of a Building's Life Cycle, Vilnius: Technika (in Lithuanian). 